\title{
Distribution and morphometric characteristics of icing fields in Svalbard
}

\author{
Elżbieta Bukowska-Jania \& Joanna Szafraniec
}

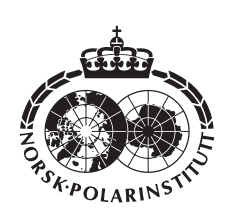

Icing fields are common in Svalbard and very diverse with respect to shape. The occurrence and spatial structure of icing fields in front of glaciers were analysed using aerial photographs (at a scale of 1:50000) taken from 19 July to 25 August 1990 - a unique set of images covering the whole archipelago in one summer season. Icing fields were observed in front of 217 glaciers. A total area of $12.3 \mathrm{~km}^{2}$ appeared to be covered by the icings. This value, from late in the ablation season, is likely to be near the seasonal minimum. Of the 217 glaciers, 192 were selected for further analysis, carried out by stereoscopic observation of the aerial photographs. Striking difference in brightness of the icing fields in comparison to the surrounded terrain combined with field experience of the geomorphic setting of its occurrence made possible the complete inventory of the icing phenomena for the whole of Svalbard. Morphometric features were measured directly on photographs and on scanned portions of them. Results from field studies of melting and the decrease of the area of icing fields at the front of two glaciers are also presented. The shape and distribution of icings depend on a set of glaciological factors and on the glacial and geomorphologic setting. The duration of frigid temperatures in the winter when the icing fields were formed is also important. Results show that oval and circular shapes are characteristic for icing fields after surviving the ablation season. These fields have an important geomorphological influence on the outwash plains that currently develop in Svalbard.

E. Bukowska-Jania, Dept. of Physical Geography, University of Silesia, Bedzinska 60, 41-200 Sosnowiec, Poland, ejania@wnoz.us.edu.pl; J. Szafraniec, Dept. of Geomorphology, University of Silesia, Bedzinska 60, 41-200 Sosnowiec, Poland.

Icing fields, also known as naled ice, are a common phenomenon in the severe, continental climate of Siberia, Alaska and north Canada (Shumskij 1955; Korejsha 1960; Carey 1973; Aleksjejev \& Ivanov 1976; Shejkman 1981; Aleksjejev 1987). Essentially frozen water reservoirs situated in the forefields of glaciers, icings consist of columnar, stratified ice formed from the freezing of successive outflows of subglacial water during winter. Icing masses can also incorporate a snow cover by saturation and freezing within it (Grzes \& Sobota 2000). The occurrence of icing fields has been described from several areas of
Svalbard (e.g. Liestøl 1976; Cegla \& Kozarski 1977; Baranowski 1977a, 1982; Åkerman 1980, 1982; Olszewski 1981, 1982; Troicki \& Kotljakov 1983; Gokhman \& Khodakov 1985; Gokhman 1987; Grzes \& Sobota 2000).

Icing fields affect the relief of outwash plains. Patches of icing fields buried by glacifluvial sediments during summer floods create undulations on outwash plains after melting (Cegla \& Kozarski 1977; Åkerman 1982).

Subpolar (polythermal) glaciers predominate in Svalbard (Baranowski 1977b; Åkerman 1982; Bamber 1987; Jania 1988; Björnsson et 


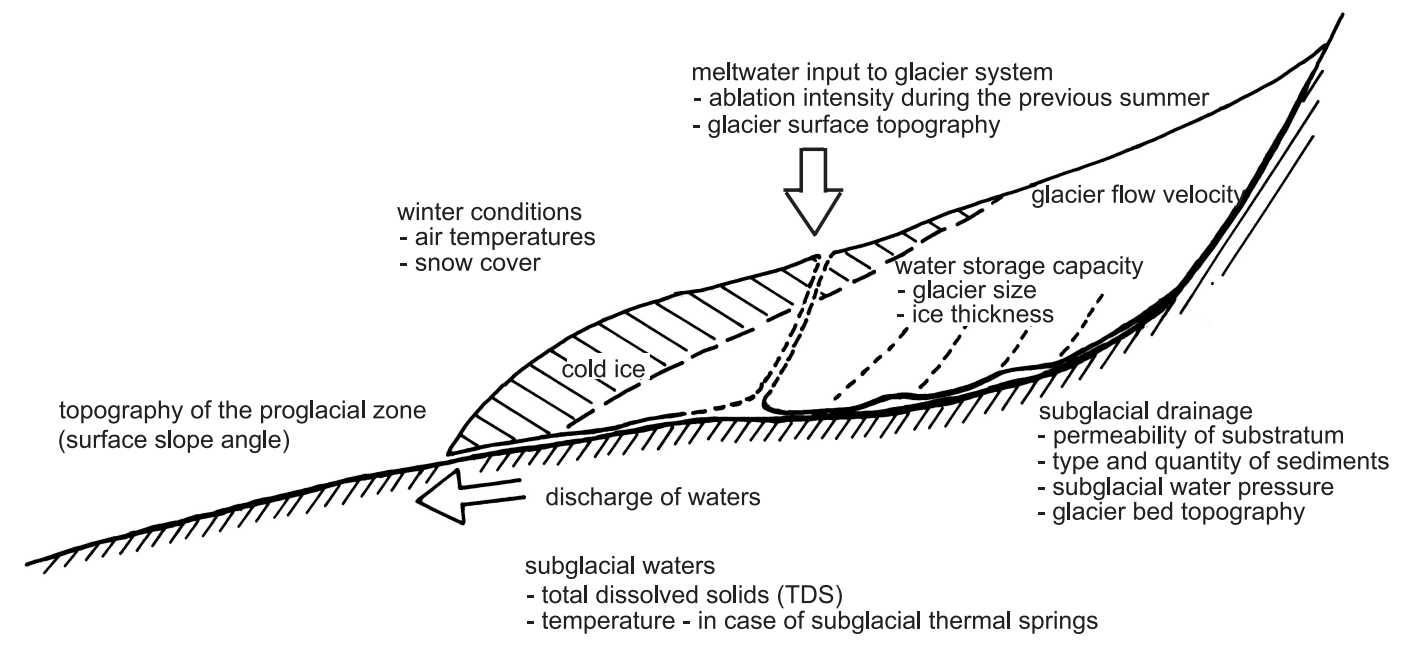

Fig. 1. Factors determining the size of icing area in winter (thermal structure of ice after Baranowski 1977b).

al. 1996; Jania et al. 1996). The thermal structure of this ice, with the accumulation area and a basal layer at the pressure melting point, permits retention of meltwater within the body of the glacier. Water storage and release during the winter reflect the development of the subglacial drainage system and its capacity in the cold season. Winter release of subglacial water is well known from Spitsbergen (e.g. Baranowski 1977b; Pulina 1984; Pulina et al. 1984), but there are no data that record how common this discharge is. A few previous works (Akerman 1980, 1982; Gokhman \& Khodakov 1985; Gokhman 1987) present records of the size and location of icing fields on Spitsbergen, but only for small areas. A complete inventory of this phenomenon for Svalbard as a whole has only recently been published, in Polish (Bukowska-Jania 2003).

One can distinguish three main factors governing the thickness and area of icing fields at the end of each winter period (Fig. 1): (1) the amount of water flowing out of the glacier in winter, (2) the air temperature levels that determine the freezing rate conditions of the water near the glacier front during winter, and (3) the topography of the glacier forefield where the icing field is formed. This paper considers (1) and (3) directly or indirectly through the distribution and extent of icing fields; (2) is not considered here. Drainage systems of glaciers are well presented in reviews by Röthlisberger \& Lang (1987) and Paterson (1994). The release of water from Svalbard glaciers during winter depends on the type and con- ductivity of its subglacial drainage. Processes responsible for the formation of all kind of icings are well described in the literature: Aleksjejev \& Ivanov (1976), Baranowski (1977a, 1982), Olszewski (1981, 1982), Åkerman (1982), Troicki \& Kotljakov (1983), Gokhman \& Khodakov (1985) and Aleksjejev (1987). There are also studies of the formation and disintegration of icings near the fronts of selected glaciers, including chemical processes within crystallized naled ice and their results (e.g. Wadham et al. 2000; Bukowska-Jania 2003; Hodgkins et al. 2004). Such interesting processes are not the focus of this work, which deals with a more general problem.

The objectives of this study were: (1) to determine the extent of icing fields in Svalbard, (2) to document and classify their morphometric features and (3) to determine which factors control their size and shape. In particular, the role of topography in the proglacial zone where the icing fields were formed was considered in order to develop a model to better understand relief formation of slightly inclined outwash plains.

\section{Methods}

The occurrence and morphometry of icing fields were analysed using vertical aerial photographs taken in Svalbard between 19 July and 25 August 1990. These colour infrared pictures have a scale of 1:50000. The vast majority of these photographs (showing 113 of the 192 glaciers includ- 
ed in this analysis) were taken between 18 and 30 July. Twenty-one photographs were taken between 2 and 16 August. Fifty-eight photographs were taken between 18 and 25 August, at the end of the ablation season. Many of the lateseason photographs were from the northern half of the west coast of Spitsbergen. The difference in when the photographs were taken may introduce a bias. However, the bias is negligible when similar topographic and glaciological settings of icing fields are being considered rather than differences in climatic conditions. No other remote sensing data of similar resolution representing a single summer season were available for the whole of Svalbard due to the extremely unstable weather conditions in the Arctic. The NASATerra/ASTER satellite imagery provide relatively high ground resolution $(15 \times 15 \mathrm{~m})$, but did not have sufficient good quality imagery to cover the entire archipelago during one summer. Cloudfree Terra/MODIS images of the archipelago (e.g. from 1999 and 2002) are available from NASA, but their resolution is too poor $(250 \times 250 \mathrm{~m})$ for identification of icing fields. Therefore, the 1990 colour stereoscopic aerial photographs represent the best current source of data for the examination of the marginal zones of the Svalbard glaciers.

The area of the icing fields and their morphometric parameters were measured directly from the aerial photographs uwith the aid of a transparent $1 \times 1 \mathrm{~mm}$ grid sheet placed on one photograph of the stereoscopic image. Later, from scanned parts of particular photographs, boundaries of naled ice were digitized using Surfer ver. 8.0 software. Differing results yielded by these two methods were within the error estimated for manually measured surfaces with the transparent grid sheet. The location of the icing fields on the floors of flat valleys, usually at low altitudes above sea level, meant that their aerial photographic image showed little distortion. The accuracy of the simple stereoscopic measurements was $\pm 0.5 \mathrm{~mm}$ in distance (corresponding to \pm 25 $\mathrm{m}$ on the ground) and $\pm 1 \mathrm{~mm}^{2}$ in area $\left( \pm 2500 \mathrm{~m}^{2}\right.$ on the ground).

Information about the thickness of icings was limited by the lack of field data during the period when the aerial photographs were taken. However, field studies of the occurrence and spatial structure of icing fields were carried out on Werenskioldbreen and Elisebreen proglacial zones (southern and north-western Spitsbergen). These studies, combined with data presented by other authors (Akerman 1982; Gokhman 1987), suggest that an average thickness of icing fields is probably approximately $1.5 \mathrm{~m}$.

The data concerning glaciers' morphometric features (Table 1) was drawn from Hagen et al.'s (1993) inventory of Svalbard glaciers.

\section{Size and distribution of icing fields}

Icing fields were identified in the forefields of 217 Svalbard glaciers (Fig. 2). The area covered in

Table 1. Morphometric parameters of the glacial regions of Svalbard.

\begin{tabular}{lccccccc}
\hline Region & $\begin{array}{c}\text { Area } \\
\left(\mathrm{km}^{2}\right)^{\mathrm{a}}\end{array}$ & $\begin{array}{c}\text { Glaciated } \\
\text { area }(\%)^{\mathrm{a}}\end{array}$ & $\begin{array}{c}\text { No. of glaciers } \\
\text { with icing at } \\
\text { their forefields }\end{array}$ & $\begin{array}{c}\text { Area of glaciers with icings } \\
\text { Total }\left(\mathrm{km}^{2}\right)^{\mathrm{a}}\end{array}$ & \multicolumn{2}{c}{$\begin{array}{c}\text { Area of icing fields } \\
\text { Mean }\left(\mathrm{km}^{2}\right)^{\mathrm{a}}\end{array}$} & Total $\left(10^{3} \mathrm{~m}^{2}\right)^{\mathrm{b}} \mathrm{Mean}^{\left(10^{3} \mathrm{~m}^{2}\right)^{\mathrm{b}}}$ \\
\hline 1. South-east Spitsbergen & 4319 & 71.3 & 3 & 482.2 & 160.7 & 175 & 58.3 \\
2. Southern Spitsbergen & 3242 & 68.1 & 12 & 1002.8 & 83.6 & 735 & 61.3 \\
3. Bellsund & 5416 & 47.7 & 39 & 908.45 & 23.29 & 1327.5 & 34 \\
4. Isfjorden & 7309 & 39.6 & 24 & 873.75 & 36.4 & 3585 & 149.3 \\
5. North-west Spitsbergen & 5443 & 59.9 & 38 & 442.5 & 11.6 & 1207.5 & 31.8 \\
6. Wijdefjorden & 7597 & 42.8 & 39 & 1245.3 & 31.9 & 1852.5 & 47.5 \\
7. North-east Spitsbergen & 5844 & 77.5 & 5 & 1216 & 243.2 & 825 & 165 \\
8. Nordaustlandet & 14997 & 75.0 & 3 & 776.5 & 259 & 272.5 & 90.8 \\
9. Edgeøya & 5160 & 42.6 & 23 & 1411.1 & 61.35 & 1252.5 & 54.5 \\
10. Barentsøya & 1298 & 47.0 & 6 & 351.2 & 58.5 & 367.5 & 61.25 \\
Svalbard & 60625 & 59.0 & 192 & 8709.8 & 45.36 & 11600 & 60.4 \\
\hline Data from & & & & & &
\end{tabular}

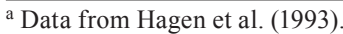

${ }^{\mathrm{b}}$ Does not include icing field areas associated with glaciers missing in Hagen et al. (1993). 


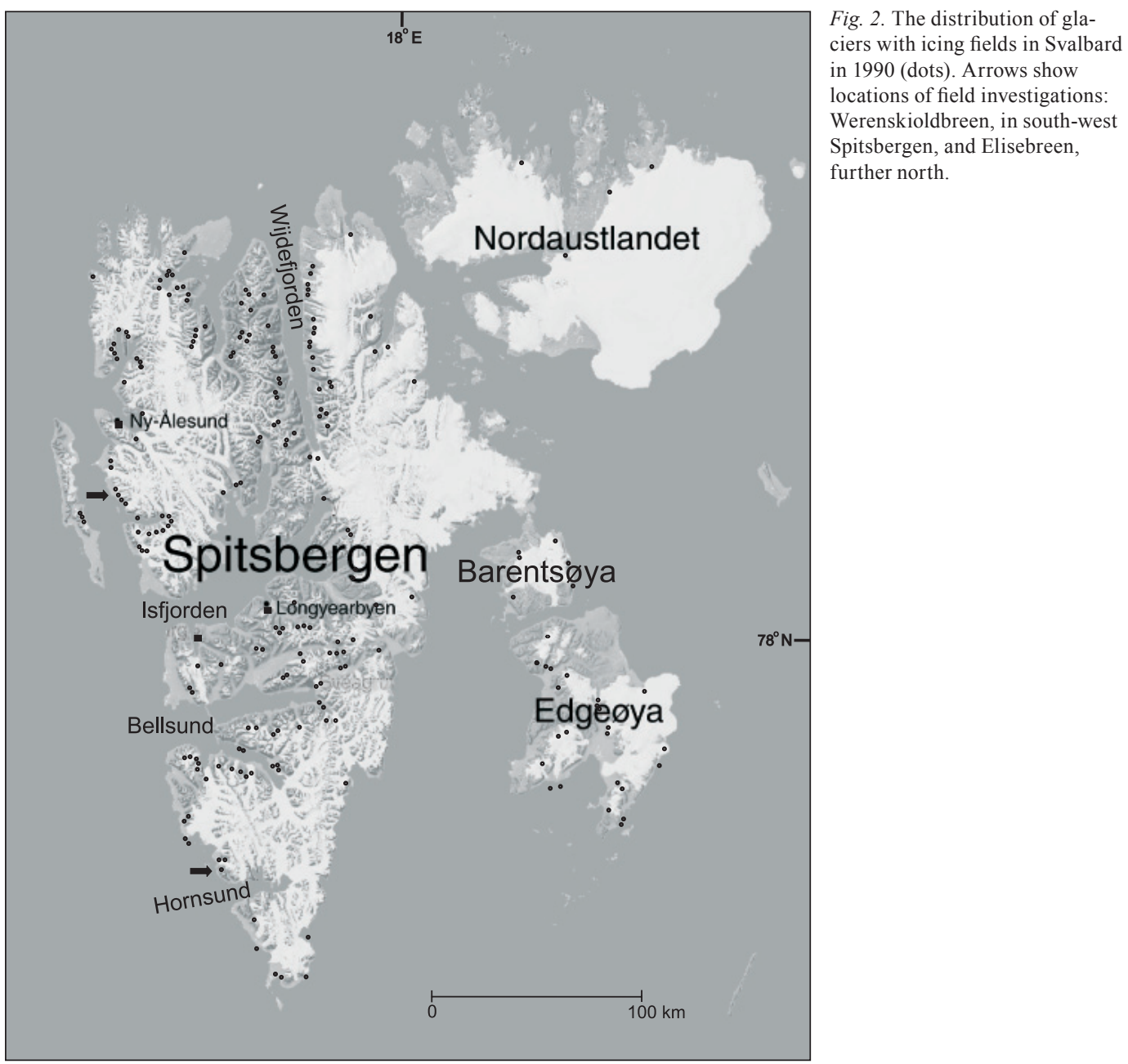

1990 by icing fields totalled $12.3 \mathrm{~km}^{2}$ (BukowskaJania 2003). During the 37-day period between when the first and last aerial photographs were taken ablation was significant and the area of icing fields had decreased. Mean air temperature in the summer of 1990 was almost $2{ }^{\circ} \mathrm{C}$ warmer than the long-term average (1935-1998) measured at the Svalbard Airport meteorological station (Hanssen-Bauer et al. 1990). It is likely that the extent of icing fields was diminishing much faster than the multiannual average due to the unusually high ablation rate in the summer of 1990 .

The spatial distribution of the icing fields in Svalbard was irregular and depended greatly on the glacier area in the region and the topography of the forefields of the glaciers. Glacial icing occurred mainly in regions with a low density of glacier cover relative to open land. Wide, gently sloping valleys favoured the formation of icing fields.

The relationship between the extent of the icing fields and the morphometric features of the associated 192 glaciers was analysed statistically. (See the Appendix, available from the authors upon request and posted online as supplementary material with this issue's table of contents at www.npolar.no.PolarResearch. The Appendix gives the morphometric parameters of glaciers and icings in their forefields. The dates of the aerial photographs on which the parameters describing the icings were based are also provided.) The 25 glaciers for which morphometric features Hagen et al. (1993) did not include in their Svalbard glacier inventory were excluded from the analysis. The data presented in Hagen et al. were obtained in the 1960s and 1970s. Since 
then, the glaciers have receded, so the relative amount of icing per glacier is underestimated in this study Nevertheless, no better data are available for the whole archipelago. The majority of studied glaciers in Svalbard have a retreat rate on the order of $20-40 \mathrm{~m} / \mathrm{yr}$ (Jania 1988). Therefore, the reduction of the length of particular glaciers can be estimated as $0.6-1.2 \mathrm{~km}$ during the period 1960(1970)-1990 (i.e. between the collection of data published in Hagen et al. and the date of the aerial photographs used in this study). The data from the Hagen et al. inventory are comprehensive for the whole archipelago, but a systemetic difference to the state of glaciers in 1990 must be recognized.

The occurrence of icing in Svalbard was considered for 10 regions of the archipelago (Fig. 3, Table 1), based on Hagen et al. (1993). The biggest icing fields, with a total area of $3600 \times 10^{3} \mathrm{~m}^{2}$, were formed in front of 24 glaciers in region 4 (the vicinity of Isfjorden). The average area of icing fields here was $150 \times 10^{3} \mathrm{~m}^{2}$ and the mean area of glaciers was $36.4 \mathrm{~km}^{2}$. Another large area of icing is found in region 6 (Wijdefjorden). Thirtynine glaciers occur in this area, which has a total icing area of $1900 \times 10^{3} \mathrm{~m}^{2}$. Regions 3 (Bellsund), 5 (north-west Spitsbergen) and 9 (Edgeøya) had similar areas of icing. Relatively small areas of icing fields were observed in region 7 (northeast Spitsbergen), 2 (southern Spitsbergen) and 1 (south-east Spitsbergen). Only six icing fields were observed in region 10 (the island of Barentsøya), with a total icing area of $370 \times 10^{3} \mathrm{~m}^{2}$.

One might expect that larger glaciers create better conditions for the retention of summer meltwater during the next winter because of their greater storage capacity, thus potentially creating larger icing fields in winter. However, direct comparison between the area of glaciers and the icing areas in front of them shows no such linear rela- tionship (Fig. 4). Factors determining discharge of subglacial water during winter are shown in Fig. 1. The most important are the volume of water stored within the glacier during the year's cold period and the type of drainage system characteristic of polythermal glaciers. Concerning the latter, glacier thickness and bed topography seem to be most important. Unfortunately, data on these features are lacking for the complete set of studied glaciers. The absence of a positive relationship between glacier size and the area of icing patches (Fig. 4) clearly suggests the influence of a combination of other factors.

To determine the relationship between glacier area and the areas of icings in their forefield and to eliminate factors affecting the data homogeneity (these factors have been listed earlier), statistical analysis was carried out on the aggregated mean data with the glaciers divided into $10 \mathrm{~km}^{2}$ classes (Table 2). For glaciers over $50 \mathrm{~km}^{2}$ the number of glaciers in each class was very low so these groups were combined. The mean area for the population of 38 glaciers was $132 \mathrm{~km}^{2}$ and the mean area of their icing fields was $176 \times 10^{3} \mathrm{~m}^{2}$. Thus, when the glaciers are roughly classified by size and the aggregated mean data are analysed, there is a strong correlation between mean glacier area and mean icing area (Fig. 5).

\section{Morphometric parameters of icing fields and their changes with ablation}

For the morphometric analysis, 121 icing fields were chosen by stereoscopic observation of aerial photographs from relatively flat proglacial areas: 98 from Spitsbergen, 18 from Edgeøya, four from Barentsøya and one from Nordaustlandet. These flat areas (slope $<5^{\circ}$ ) with distinct icing edges were selected to minimize distortion due

Table 2. Aggregated mean data showing glacier area and icing field area in front of the glacier according to glacier size.

\begin{tabular}{ccccc}
\hline $\begin{array}{c}\text { Glacier area } \\
\left(\mathrm{km}^{2}\right)\end{array}$ & $\begin{array}{c}\text { No. of } \\
\text { glaciers }\end{array}$ & $\begin{array}{c}\text { Mean area of } \\
\text { glaciers }\left(\mathrm{km}^{2}\right)\end{array}$ & $\begin{array}{c}\text { Mean area of icing } \\
\text { fields }\left(10^{3} \mathrm{~m}^{2}\right)\end{array}$ & $\begin{array}{c}\text { Mean icing area as \% } \\
\text { of mean glacier area }\end{array}$ \\
\hline $0-10$ & 80 & 5.1 & 25.82 & $0.51 \%$ \\
$10-20$ & 40 & 13.2 & 40.38 & $0.30 \%$ \\
$20-30$ & 14 & 25.5 & 75.89 & $0.30 \%$ \\
$30-40$ & 14 & 34.2 & 93.75 & $0.21 \%$ \\
$40-50$ & 6 & 43.7 & 78.33 & $0.18 \%$ \\
$>50$ & 38 & 131.7 & 175.80 & $0.13 \%$ \\
\hline
\end{tabular}




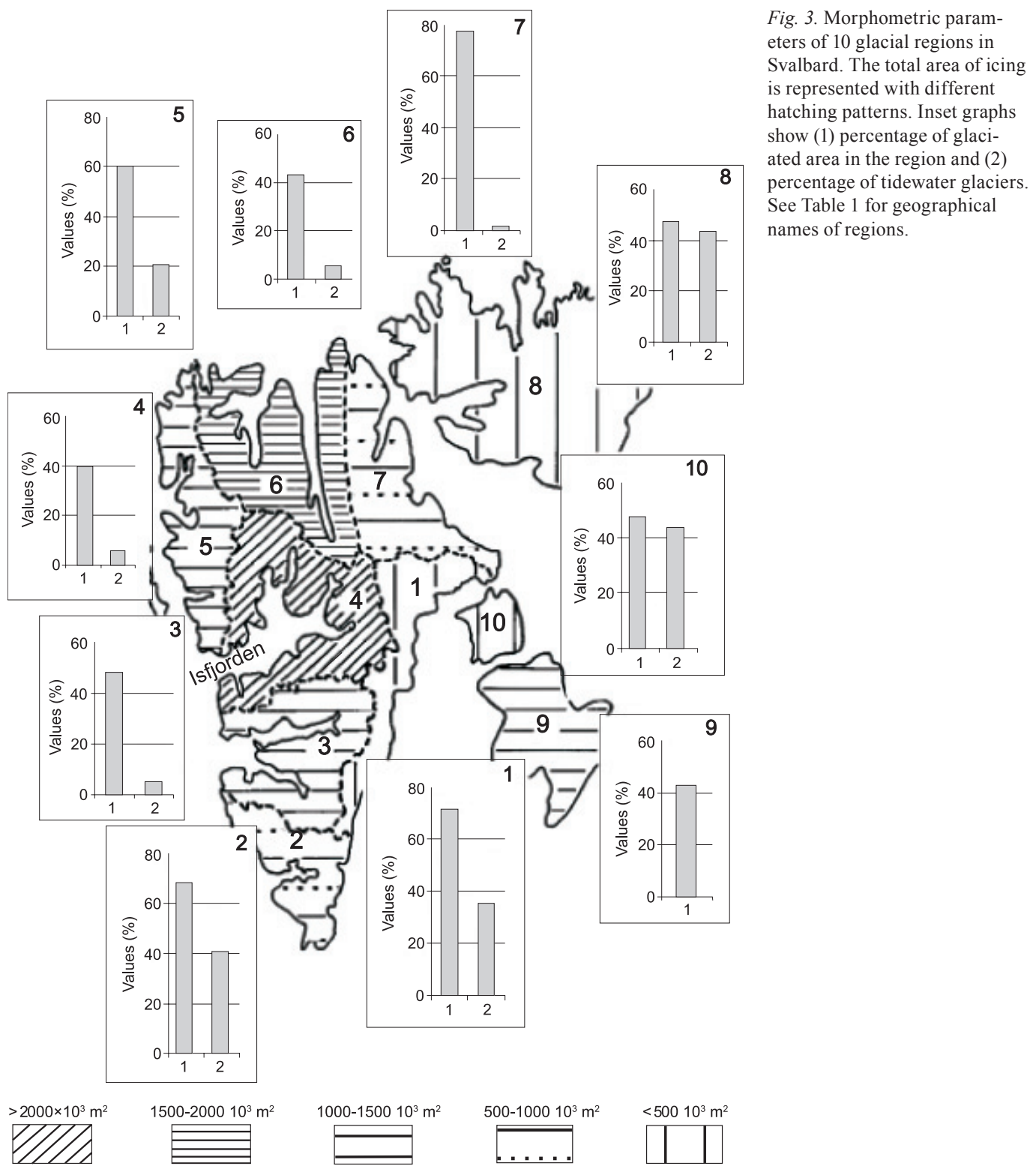

to changes in elevation and to permit mapping of their boundaries in similar topographic conditions (Fig. 6). Simple morphometric parameters were measured on scanned portions of the aerial photographs: maximum length of icing field (L), maximum width $(B$, measured perpendicular to the line of maximum length), perimeter (D) and surface area (A). These values were used for the following calculations: mean width $\left(\mathrm{B}_{\mathrm{s}}=\mathrm{A}\right.$ / $\mathrm{L})$, elongation factor $\left(\lambda=\mathrm{L} / \mathrm{B}_{\mathrm{s}}\right)$ and development factor $(\mathrm{R}$, ratio of the icing perimeter to the circle perimeter with the same area of the icing: $D / 2$ $\sqrt{\Pi A})$. The analysis of changes in the shape of icing fields during the ablation season was based on elongation and development factors.

In the majority of cases studied, icing fields developed in the inner parts of the proglacial area and were closely related to the glacier drainage and the inner marginal zone "capacity" (Fig. 7), here defined as the area between the glacier margin 
Fig. 4. Relationship between the area of 192 glaciers analysed statistically and the area of icing in their forefields in 1990.

Fig. 5. Relationship between the mean size of glaciers and the mean areas of their icing.
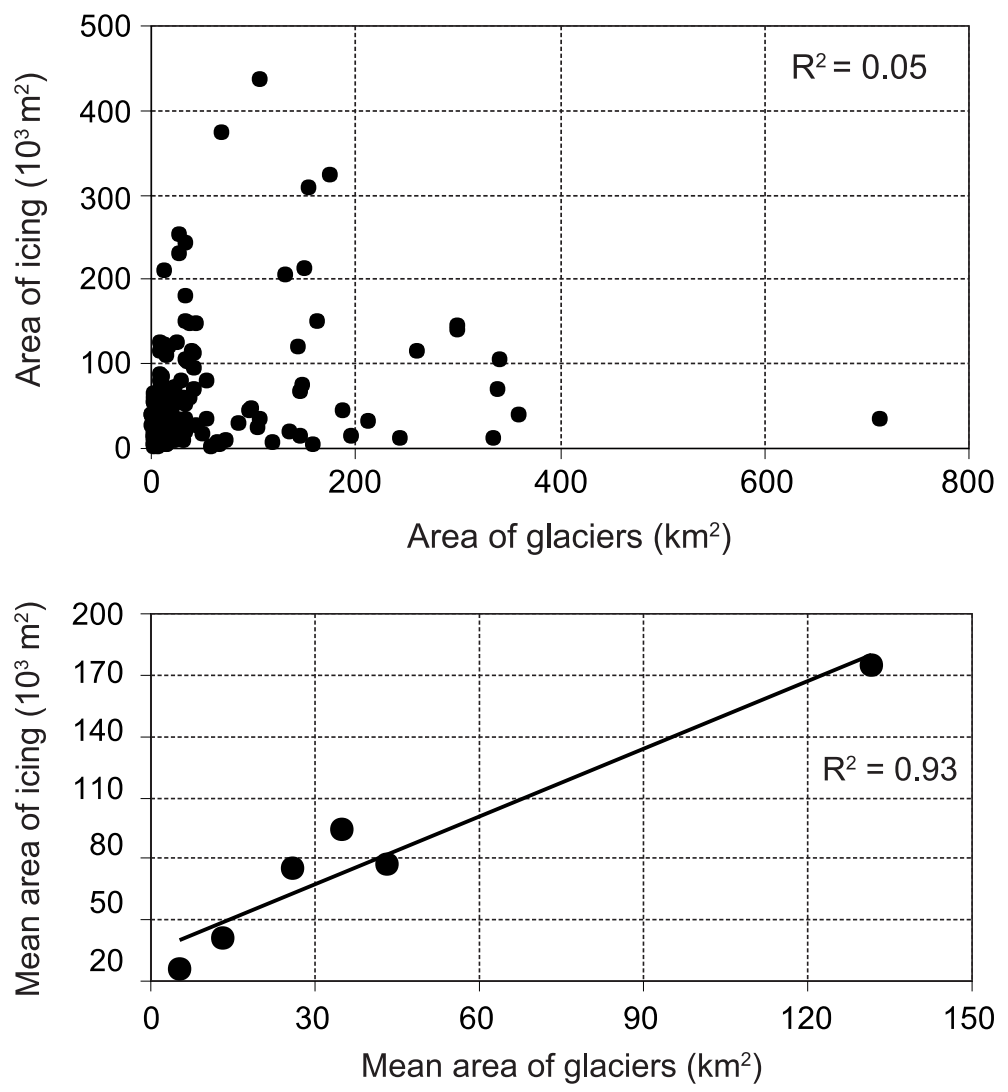

and the arch of frontal and lateral moraines. The larger this area, the higher potential for icing field growth. Icing fields occurred typically in one of eight glacial-geomorphological settings depicted in Fig. 7. Each of these types (a-h in Fig. 7) represented between $9 \%$ and $19 \%$ of the total number of icing fields, with no group dominant. Many of the icing fields developed where the subglacial tunnels emerge along the glacier front (Fig. 7a). They have compact shapes, usually forced by the bed topography, which is reflected in the lowest elongation values ( $\lambda=1.11$ on average) and development factors $(\mathrm{R}=1.34$ on average). These forms show increased thickness because of the close proximity of the feeding source (Grzes \& Sobota 2000) and the relatively small capacity of the inner marginal zone. They often survive the ablation season without major changes in their sizes and, especially, in their shapes.

When the capacity of the inner marginal zone is sufficient, icing fields that form close to the glacier front continue further in proglacial river channels (Fig. 7b). Their shapes are then more complicated and elongated. During the ablation season, the part of the icing spreading in the river channel usually melts completely. Ablation and the mechanical deportation of ice with the glacier river flow seem to be responsible. Other examples of situations in which icings occur are on outwash fans in the marginal (Fig. 7b) and extramarginal zones (Fig. 7c), as well as on outwash fans spreading close to lateral rivers outlets (Fig. 7d). These forms have large areas but more compact shapes - triangle-, bell- or fan-like (on average L is three times longer than $B_{s}$ ).

Icing fields in river channel beds usually have elongated forms. These were found along lateral moraines (Fig. 7e) and in proglacial areas, crossing end moraines (Fig. 7f). Their length was observed to be 5 to 10 times their mean width. Shaped by the river channel course, they tend to be sinuous in form.

The most complicated icing shapes, with elongation values up to 22 , occur only in the extramarginal zone (Fig. 7g), in somewhat steeper drainage areas. They develop beyond end 

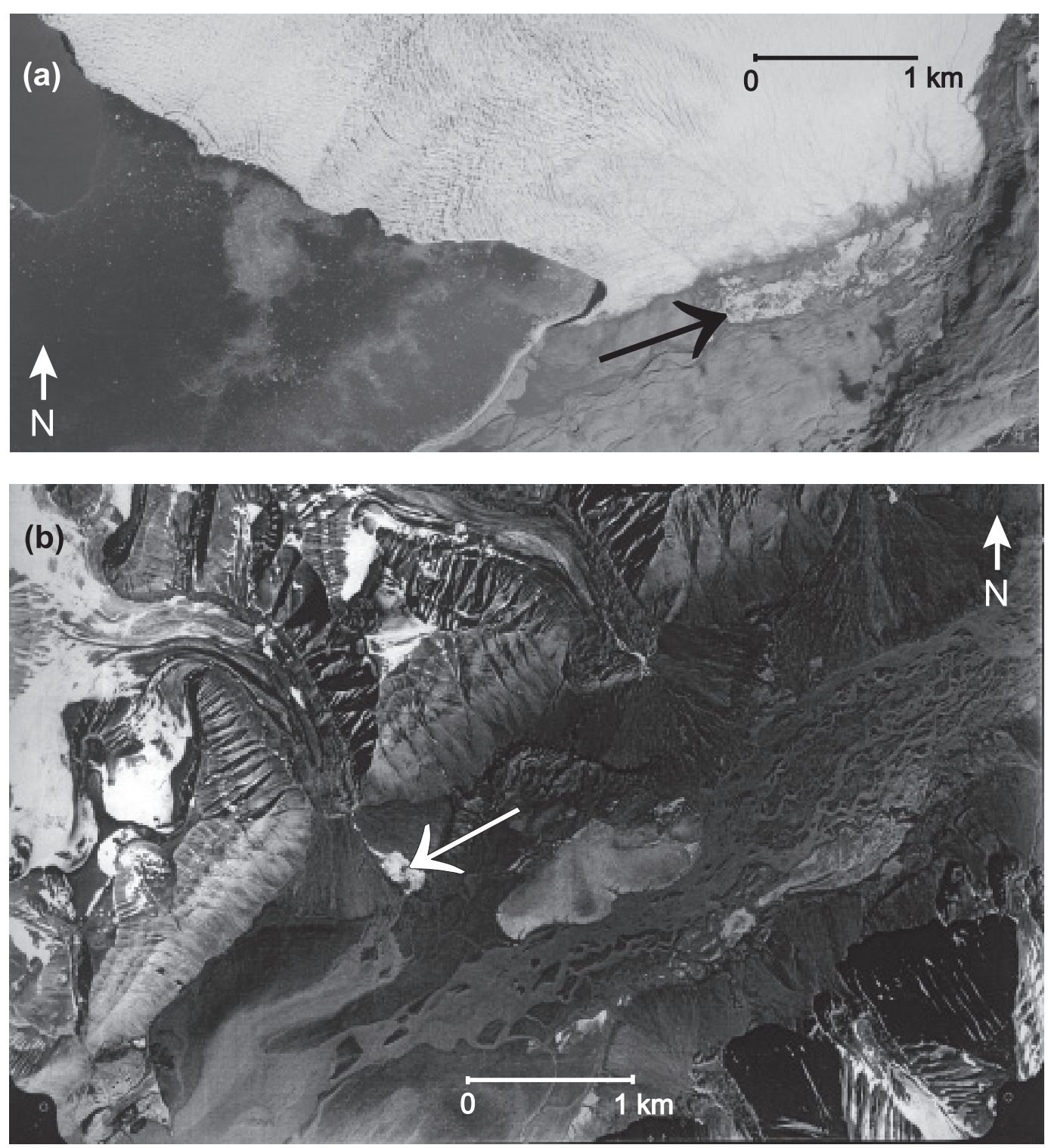

Fig. 6. (a) Icing fields, indicated with arrows, on aerial photographs from 1990: (a) the lateral zone of Austre Torellbreen (portion of orthophotomap by Jania \& Kolondra [2002]) (compare to Fig. 7d); and (b) the extramarginal zone of Höganäsbreen (portion of aerial photograph no. 1880, taken 22 July, courtesy of the Norwegian Polar Institute).(compare Fig. 7g).

moraines in beds of extramarginal river channels and extend into outwash fans downstream, close to outlets into the bigger valleys. Their shapes are usually bell-like. Although the icing fields described here were situated in areas of relatively low relief, it is likely that icing bodies would develop further from the glacier front in steeper marginal zones.

The most diverse group of icings are "bifurcat- ed" forms (Olszewski 1982). They originate in the inner marginal zones and extend beyond end moraines (Fig. 7h). Their shapes are the most variable, possibly due to large winter discharges of subglacial water and a relatively large drainage area capacity. These forms also have the largest elongation factor (on average $\mathrm{L}$ is 10 times longer than $B_{s}$ ) and development factor ( $R$ values $>2.5$ ). 

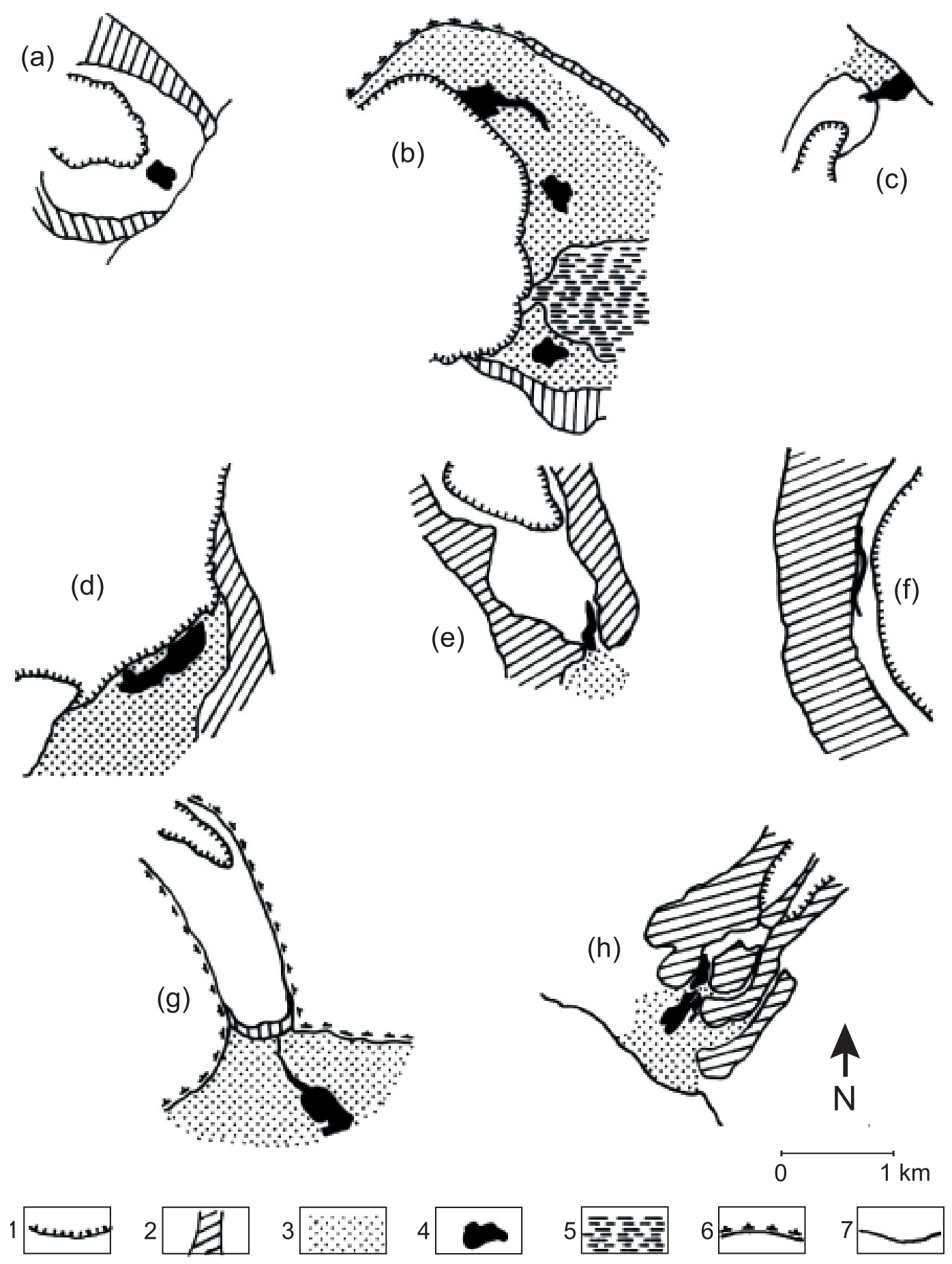

Fig. 7. Glacial-geomorphologic settings, where icing fields were identified: (1) glacier, (2) end and lateral moraines, (3) outwash plain, (4) icing fields, (5) lake, (6) slope, (7) shoreline. (a) Unnamed glacier (aerial photograph no. 2765; in Hagen et al. [1993] inventory no. 31320. (b) Renardbreen (2060, 13112). (c) Unnamed glacier (6533, 15604). (d) Austre Torellbreen (4118, 12503; compare Fig. 6a). (e) Seidbreen $(2417,3112)$. (f) Sysselmannbreen $(2000,13222)$. (g) Höganäsbreen $(1880$, 13531; compare Fig. 6b). (h) Vallakrabreen $(1883,13413)$. 


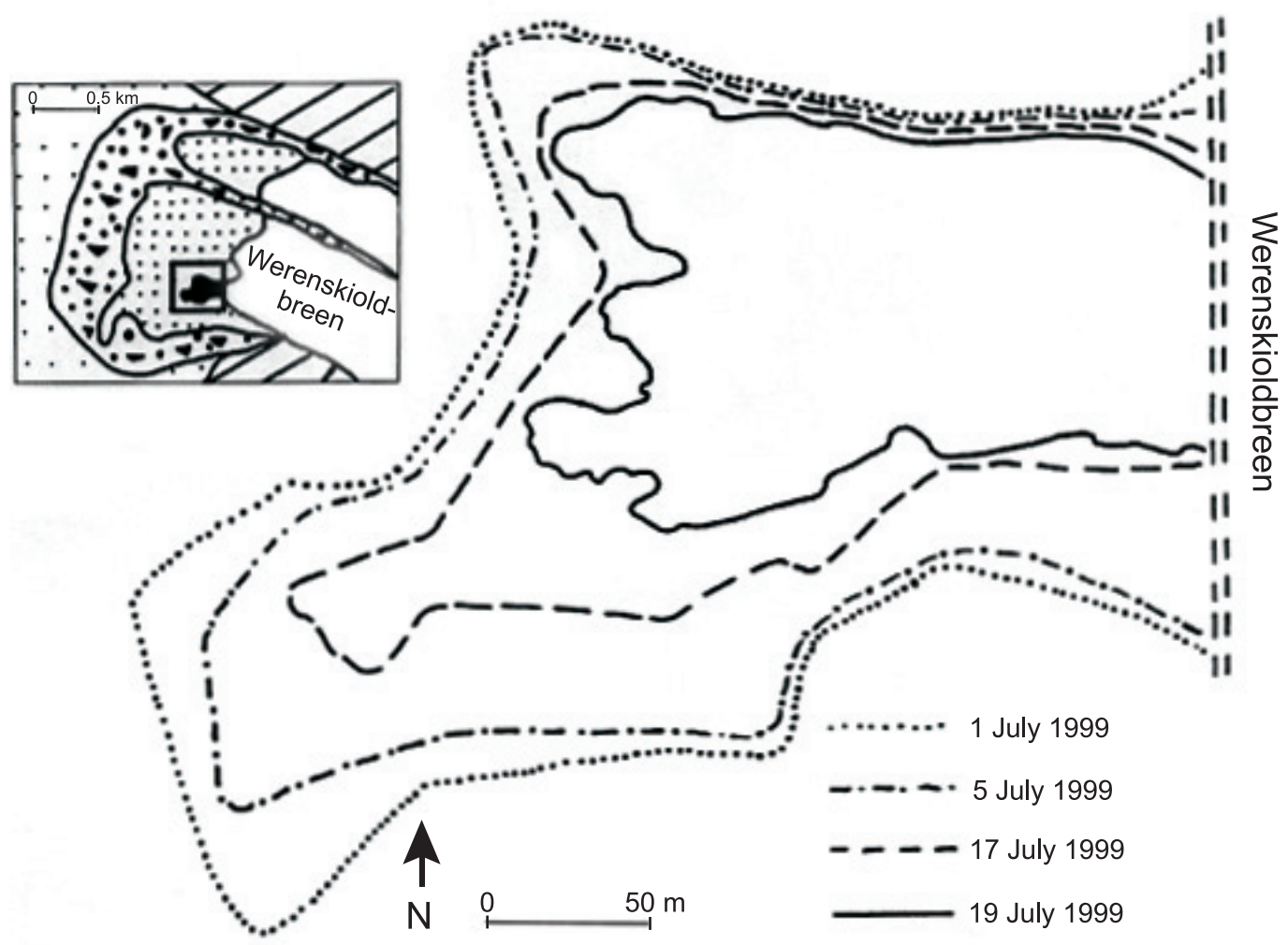

Fig. 8. Disintegration of the southern icing field in front of the Werenskioldbreen glacier between 1 and 19 July 1999.

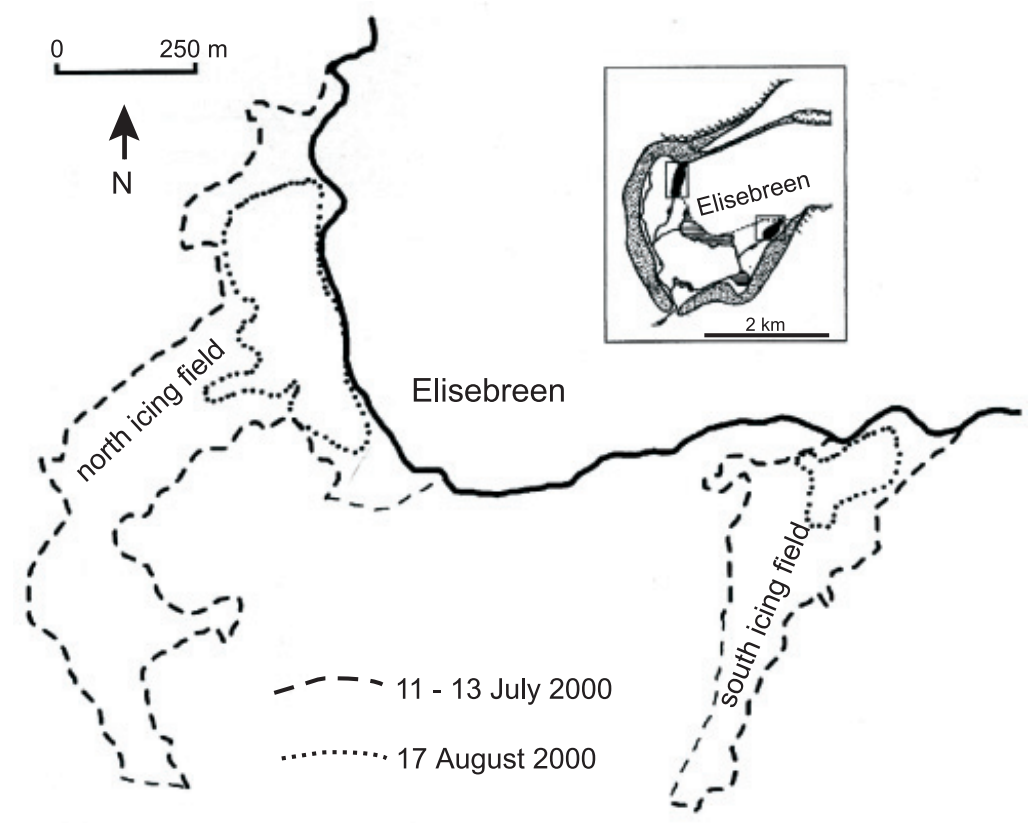


Fig. 10. Relation between date of registration of the 121 glacier icing fields by particular series of aerial photographs in summer 1990 and the elongation factor of icing fields $(\lambda$, explanation in the text). particular points (on photograph dates) are indicated. Number of analysed causes for

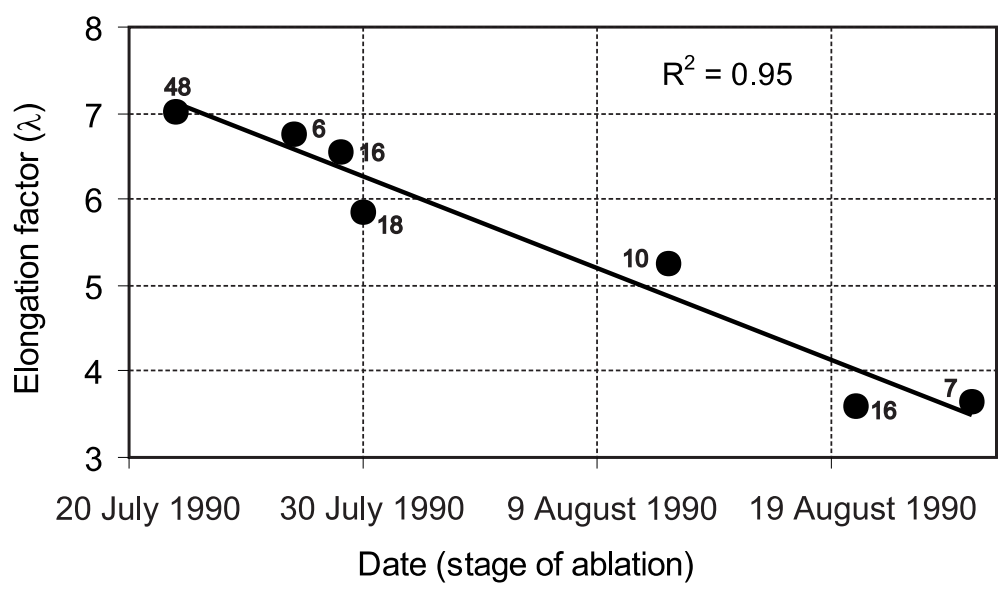

\section{Field studies}

Field studies were carried out on Werenskioldbreen and Elisebreen in 1999 and 2000, respectively, to obtain a time series of the planar shape and area changes of the icing fields during the melt season. In the case of Werenskioldbreen, changes in icing geometry were mapped from 1 to 19 July 1999, the period of most intense ablation (Fig. 8). A variety of global positioning system (GPS) survey techniques were used to measure the shape and area changes of the southern icing fields (Bukowska-Jania 2003). These consisted of navigational and precise kinematics methods. The precise static GPS method was employed for measurements of more than a dozen points marked by wooden poles around the contour of the naled ice. These reference poles were later used for measuring distances by geodetic tape and compass to the retreated limit of this icing field. Over the 19-day interval, the overall icing field length decreased by ca. $46 \%$, with up to $39 \%$ occurring between 17 and 19 July. This loss is attributed to the extremely warm temperatures (maximum air temperature up to $18^{\circ} \mathrm{C}$ ) caused by a strong foehn wind. (Meteorological data from the Polish Polar Station in Hornsund suggest that the second half of this summer was not so warm.) Initially, the elongation factor increased from 2.30 (on 1 July) to 3.33 (on 17 July). This was caused by a pattern of icing disintegration which began laterally, along the y axis. However, at the same time, the length of the icing field was largely maintained due to its partial location in a proglacial river channel. In the period 17-19 July, there was a pronounced reduction in the elongation factor to 1.77 .
This indicated that the form had already reached its equilibrium state of shape compactness in the middle of that ablation season.

Further changes were observed in the northon 17 August 2000, the second half of the ablation season. In this case, the precise GPS kinematic method was used to contour icing patches in July and compare them with the corresponding geocoded Terra/ASTER satellite imagery (courtesy of Z. Perski). Over this time, both icings showed a substantial decrease of all parameters, particularly length. The northern icing decreased by $76 \%$ and the southern by $72 \%$. The elongation factor decreased dramatically from 4.22 to 0.92 in the case of the northern icing and from 5.98 to 2.71 for the southern one. The shape of all forms became more rounded and the development factor decreased from 2.29 to 1.54 for the northern icing and from 1.87 to 1.22 for the southern icing.

Icing measurements from the aerial photographs taken in 1990 provide an indirect source of time-dependent data about the change in shape of the 121 icing fields. Forty-eight were photographed on 22 July, 6 on 27 July, 16 on 29 July, 18 on 30 July, 10 on 12 August, 16 on 20 August and 7 on 25 August 1990. In our assessment we have roughly equated the first date with not very advanced icing field disintegration by ablation. Clearly this may be an erroneous assumption, as shown by the observed reduction in the length of the icing studied in 1999, all of which occurred before 22 July (see Fig. 8). However, in the first period of the summer season, icing shapes were very similar to those from the end of the winter ern and southern icings of Elisebreen (Fig. 9). Their extent was mapped during 11-13 July and 
season (results of survey by the navigational GPS by M. Burzyk in April 1999: pers. comm. 1999). This is due to the fact that the process of destruction usually began with the superficial melting of icing bodies which led to their thinning. Disintegration of icing continued with the formation of separated fragments and melting out of the thinnest parts of the fields. Consequently, changes of their shape and size were observed mainly in the second part of the ablation season.

Regardless of the geomorphological settings in which icing bodies occurred, disintegration due to melting is always an important factor for the morphometric features of icing fields. The indirect evidence of time-dependence and the elongation factor $(\lambda)$ is shown in Fig. 10. It shows the relationship between the date of aerial photographs and the shape of icings, i.e. the elongation factor. The average elongation factor for the whole population of icing fields changed from $\lambda=7$ to $\lambda \sim 3.5$ during 35 days (22 July-25 August 1990). In other words, icing fields became more oval or circular in shape.

Among the icing fields which survived the ablation season (photographed on 20 and 25 August 1990), three basic groups representing 69\% of cases. The largest group contains the icings bordering the glacier fronts (group 1). These icings survived the ablation season due to their large initial thickness and compactness of form. Most of the energy used for ablation resulted in a decrease in icing field thickness. Their shapes became oval or circular. The other two groups of icing bodies were those found in depressions in end moraines (group 2) and those extending from end moraine areas to extramarginal outwash fans (group 3). Again, survival was due to large icing thickness, reaching up to $8 \mathrm{~m}$ (Grzes \& Sobota 2000), resulting from the local topography. The elongation factor in the first and the third groups whose forms were rather compact remained similar throughout the ablation season. However, the elongation factor for the second group of icings decreased to half. The other $31 \%$ of icing fields (group 4) represented specific glacial and geomorphologic situations more complicated than those emphasized here.

\section{Conclusion}

This is the first comprehensive inventory of icing fields carried out for a large High Arctic archi- pelago. Despite certain limitations in the homogeneity and, therefore, the reliability of the interpretations which were derived from 1990 aerial photographs, we were able to illustrate some significant aspects of the spatial distribution of icing fields and to determine the most important factors that control them.

Icing fields occur on all larger Svalbard islands, being a typical phenomenon in the glacial/periglacial environment there. They were observed downstream of 217 glaciers and cover a total area of $12.3 \mathrm{~km}^{2}$. Because the images were taken during a period of maximum ablation, icing field sizes as determined from the aerial photographs should be regarded as minimum estimates. The 1990 summer was significantly warmer than the long-term (1935-1998) average, which may imply that the average size of the icing fields is generally larger than we have indicated here.

The investigations allow us to make to the following conclusions:

(1) The occurrence of icing fields in Svalbard shows considerable regional differences and depends mostly on the size of glaciers and the topography of their forefield (Figs. 1, 4). Flat proglacial zones in relatively wide valleys favour the formation of larger icing fields.

(2) Icing fields in Svalbard are very variable in terms of their shape. The shape is closely associated with the particular glacial and geomorphological context. Eight different types of icing fields were identified based on their glacial-geomorphological settings (Fig. 7).

(3) As ablation progresses, all the morphometric parameters of the icing fields decrease, especially the elongation factor (Fig. 10). Icing fields that survive the ablation season, particularly those in proglacial outwash plains close to a glacier front, are typically circular or oval forms. When covered by fluvioglacial deposits in the next summer season, an inversion of the outwash plain relief might develop due to melting of buried ice bodies (fossil icing fields).

(4) Circular and oval icing fields have a considerable geomorphological influence on the development of the outwash plains relief currently formed in Svalbard.

Acknowledgements.-This research is part of project no. 6PO4E 014 21, financed by the State Committee for Scientific Research, Poland. We are grateful to Elisabeth Issakson (Norwegian Polar Institute) for arranging access to the aerial photographs of Svalbard, Zbigniew Perski (University of 
Silesia) for examination of the Terra/ASTER satellite imagery of Elisebreen and Leszek Kolondra (University of Silesia) for providing the portion of orthophotomap with icing fields. Peter Walsh, Tom van Loon and specially Evelyn Dowdeswell kindly corrected English drafts of the manuscript and provided extremely valuable editorial advise.

\section{References}

Åkerman, J. 1980: Studies on periglacial geomorphology in west Spitsbergen. Geogr. Inst. Ser. Proc. 89, 150-227. Lund University.

Åkerman, J. 1982: Studies on naledi (icings) in western Spitsbergen. In H. M. French (ed.): Proceedings, Fourth Canadian Permafrost Conference. Pp. 189-202. Ottawa: Natural Research Council of Canada.

Aleksjejev, V. R. 1987: Naljedi. (Icing.) Novosybirsk: Izdatielstvo Nauka.

Aleksjejev, V. R. \& Ivanov, A. V. 1976: Kriogiennaja metamorfizacja prirodnykh vod i jejo rol v krygovorotie vieschestv. (Cryogenic metamorphism of natural water and its influence on matter circulation.) Dokl. Inst. Gieografi Sibiri i Dalnogo Vostoka 46, 31-40.

Bamber, J. L. 1987: Internal reflecting horizons in Spitsbergen Glaciers. Ann. Glaciol. 9, 5-10.

Baranowski, S. 1977a: Naled type of ice in front of some Spitsbergen glaciers. In S. Baranowski \& A. Jahn (eds.): Results of investigations of the Polish Scientific Spitsbergen Expeditions 1970-1974, 2. Acta Univ. Wratislav. 387, 85-89.

Baranowski, S. 1977b: Subpolarne lodowce Spitsbergenu na tle klimatu tego regionu. (Subpolar glaciers in Spitsbergen and the climate of this region.) Acta Univ. Wratislav. 393.

Baranowski, S. 1982: Naled ice in front of some Spitsbergen glaciers. J. Glaciol. 28, 211-214.

Björnsson, H., Gjessing, Y., Hamran, S.-E., Hagen, J. O. Liestøl, O., Pálsson, F. \& Erlingsson, B. 1996: The thermal regime of sub-polar glaciers mapped by multi-frequency radio-echo sounding. J. Glaciol. 42, 23-32.

Bukowska-Jania, E. 2003: Rola systemu lodowcowego w obiegu weglanu wapnia $w$ srodowisku przyrodniczym. (The role of glacier system in the migration of calcium carbonate in the natural environment.) Prace Naukowe 2103. Katowice, Poland: Wydawnictwo Uniwersytetu Slaskiego.

Carey, K. L. 1973: Icings developed from surface water and ground water. Monograph MIII-D3. Hanover, NH: U.S Army Corps of Engineers, Cold Regions Research and Engineering Laboratory.

Cegla, J. \& Kozarski, S. 1977: Sedimentary and geomorphological consequences of the occurrence of naled sheets on the outwash plain of the Gås Glacier, Soerkappland, Spitsbergen. In S. Baranowski \& A. Jahn (eds.): Results of inves tigations of the Polish Scientific Spitsbergen Expeditions 1970-1974, 2. Acta Univ. Wratislav. 387, 63-84.

Gokhman, V. V. 1987: Distribution and conditions of formation of glacial icings on Spitsbergen. Polar Geogr. Geol. 11, 249-260.

Gokhman, V. V. \& Khodakov, V. G. 1985: Gidrologija lednikov i lednikovyh basjejnov. (Hydrology of glaciers and glacier basins.) In V. M. Kotljakov (ed.): Glacjologia Shpitsbergena. (Glaciology of Spitsbergen.) Pp. 64-78. Moskva: Nauka.

Grzes, M. \& Sobota, I. 2000: Winter snow accumulation and discharge from the Waldemar Glacier, northwestern Spits- bergen in 1996-1998. Pol. Polar Res. 21, 19-32.

Hagen, J. O., Liestøl, O., Roland, E. \& Jorgensen, T. 1993. Glacier atlas of Svalbard and Jan Mayen. Nor. Polarinst. Medd. 141. Oslo.

Hanssen-Bauer, I., Kristensen Solås, M. \& Steffensen, E. L. 1990: The climate of Spitsbergen. Klima Nor. Meteorol. Inst. Rapp. 39/90.

Hodgkins, R., Tranter, M. \& Dowdeswell, J. A. 2004: The characteristics and formation of a high-Arctic proglacial icing. Geogr. Ann. 86A, 265-275.

Jania, J. 1988: Klasyfikacja i cechy morfometryczne lodowcow otoczenia Hornsundu, Spitsbergen. (The classification and morphometric features of the Hornsund glaciers, Spitsbergen.) In Wyprawy Polarne Uniw. Sl. 2, 12-47.

Jania, J. \& Kolondra, L. \& Aas, H. F. (eds.) 2002: Werenskioldbreen and surrounding areas. Spitsbergen, Svalbard, Norway. Orthophotomap 1: 25000 . University of Silesia and Norwegian Polar Institute.

Jania, J., Mochnacki, D. \& Gadek, B. 1996: The thermal structure of Hansbreen, a tidewater glacier in southern Spitsbergen, Svalbard. Polar Res. 15, 53-66.

Korejsha, M. M. 1960: O sootnoshenii sovriemiennogo oledinieja i tarynov (naledii) hriebieta Suntar-Hajaty. (Interactions between a contemporary glaciation and naled ice of the Suntar-Hajaty ridge.) Gljacjologicheskije Isledovanija $5,124-130$

Liestøl, O. 1976: Pingos, springs and permafrost in Spitsbergen. Nor. Polarinst. Arb. 1975, 7-29.

Olszewski, A. 1981: Warunki wystepowania nalodzi, ich rozwoj i degradacja na Ziemi Oskara II, Spitsbergen. (Conditions of icing field occurrence, their development and degradation in Oscar II Land, Spitsbergen.) Czasopismo Geogr. 52, 397-435.

Olszewski, A. 1982: Icings and their geomorphological significance exemplified from Oscar II Land and Prins Karls Forland, Svalbard. Acta Univ. Nicolai Copernic. Geogr. 16, 91-122.

Paterson, W. S. B. 1994: The physics of glaciers. Second edition. Oxford: Pergamon Press.

Pulina, M. 1984: The effects of cryochemical processes in the glaciers and permafrost in Spitsbergen. Pol. Polar Res. 5, 137-163

Pulina, M., Pereyma, J., Kida, J. \& Krawczyk, W. E., 1984: Characteristic of the polar hydrological year 1979/1980 in the basin Werenskiold Glacier, SW Spitsbergen. Pol. Polar Res. 5, 165-182.

Röthlisberger, H. \& Lang, H. 1987: Glacial hydrology. In A. M. Gurner \& M. J. Clark (eds.): Glacio-fluvial sediment transfer. An alpine perspective. Pp. 207-284. London: J. Whiley and Sons.

Shejkman, V. S. 1981: O klasifikacji epilednikovyh naledi (The classification of naled ice fields in the internal marginal zone of glaciers.) In V. R. Aleleksjejev (ed.): Naledi Sibiri i Dalnevo Vastoka. (The icing of Siberia and the Far East.) Pp. 23-30. Novosibirsk: Izdatelstvo Nauko.

Shumskij, P. A. 1955: Osnovy strukturalnogo ledovjedienija. (Principles of structural glaciology.) Moskva: Izdatielstvo AN SSSR.

Troicki, L. S. \& Kotljakov, V. G. 1983: O priljednikovyh naljedjah na Shpitsbergenie. (The glacier naled ice in Spitsbergen.) Mater. Glacjologicheskih Issled. 21, 88-95.

Wadham, J. L., Tranter, M. \& Dowdeswell, J. A. 2000: Hydrochemistry of meltwaters draning a polythermal-based, High-Arctic glacier, south Svalbard: II. Winter and early spring. Hydrol. Process. 14, 1767-1786. 
